\title{
Spranto Lost
}

\section{Chris Wallace-Crabbe}

Published online: 13 November 2009

(C) Springer Science + Business Media B.V. 2009

Keywords Religious poem $\cdot$ Metaphysical poem

Once on a time

Time was a language

Once on a time

Old everybody spoke

In God's Esperanto

Once in the language

They made a lot of bricks

A bric-a-brac of bricks

To stack and stick and stack

Way up to heaven

A tower in clouds

Aloud in the cloud

Stack rattle pop

And they all could speak

In God's Esperanto

Not happy, little men

Said the god like thunder

Booming broadly

Against that babble

Of people from Babel

C. Wallace-Crabbe $(\bowtie)$

The Australian Centre, School of Historical Studies, University of Melbourne, Melbourne, Australia e-mail: ckwc@unimelb.edu.au 
So he broke their language

Like bits of firewood

And blew them all away

Across the desert

Of differing tongues

Off now they scattered

Camelback muleback

Misunderstanding

But yearning still for

The language umbrella 